\title{
Profile information on CO from SCIAMACHY observations using cloud slicing and comparison with model simulations
}

\author{
C. Liu ${ }^{1, *}$, S. Beirle ${ }^{1}$, T. Butler ${ }^{1, * *}$, P. Hoor ${ }^{1, * * *}$, C. Frankenberg ${ }^{2}$, P. Jöckel ${ }^{1, * * * *}$, M. Penning de Vries ${ }^{1}$, U. Platt ${ }^{3}$, \\ A. Pozzer ${ }^{1,4}$, M. G. Lawrence ${ }^{1, * *}$, J. Lelieveld ${ }^{1,4}$, H. Tost $^{1, * * *}$, and T. Wagner ${ }^{1}$ \\ ${ }^{1}$ Max-Planck-Institute for Chemistry, Mainz, Germany \\ ${ }^{2}$ Jet Propulsion Laboratory, California Institute of Technology, Pasadena, CA, USA \\ ${ }^{3}$ Institute for Environmental Physics, University of Heidelberg, Germany \\ ${ }^{4}$ Cyprus Institute, Nicosia, Cyprus \\ * now at: Harvard-Smithsonian Center for Astrophysics, Cambridge, MA, USA \\ ** now at: Institute for Advanced Sustainability Studies e.V., Potsdam, Germany \\ **** now at: Institute for Atmospheric Physics, University Mainz, Germany \\ **** now at: Institut für Physik der Atmosphäre, Deutsches Zentrum für Luft- und Raumfahrt (DLR), Oberpfaffenhofen, \\ Germany
}

Correspondence to: T. Wagner (thomas.wagner@mpic.de)

Received: 11 April 2013 - Published in Atmos. Chem. Phys. Discuss.: 2 May 2013

Revised: 29 December 2013 - Accepted: 6 January 2014 - Published: 14 February 2014

\begin{abstract}
We apply a cloud slicing technique (CST), originally developed for Total Ozone Mapping Spectrometer (TOMS) ozone observations, to CO vertical column densities retrieved from the SCanning Imaging Absorption spectroMeter for Atmospheric CHartographY (SCIAMACHY). CST makes use of the shielding effect of clouds and combines trace gas column measurements of cloudy pixels with different cloud heights to retrieve fractional columns aloft. Here we determine seasonal mean tropospheric $\mathrm{CO}$ profiles at a vertical resolution of about $1 \mathrm{~km}$, which is much finer than what can be obtained from thermal infrared (IR) instruments. However, since both the atmospheric $\mathrm{CO}$ profiles and the effective cloud heights depend systematically on meteorology, and in addition part of the retrieved signal originates from the clear part of the satellite ground pixel, the profiles retrieved from the CST have to be interpreted with care. We compare the seasonal mean SCIAMACHY CO profiles with the output from two atmospheric models sampled in the same way as the satellite observations. We find in general good agreement of the spatial patterns, but systematic differences in the absolute values are observed in both hemispheres (more strongly in the Northern Hemisphere), indicating that the source strengths in the emission inventories are probably underestimated.
\end{abstract}

\section{Introduction}

Carbon monoxide (CO) is emitted into the atmosphere by natural and anthropogenic processes. It is toxic in high concentrations and is an important precursor of tropospheric ozone (e.g. Crutzen and Gidel, 1983). The atmospheric lifetime of CO is typically weeks to months (Cicerone, 1988), thus it is an ideal tracer for atmospheric transport processes (Logan et al., 1981; Lelieveld et al., 2001; Shindell et al., 2006).

It has been shown in several studies, including satellite observations (e.g. Gloudemans et al., 2006, 2009; de Laat et al., 2006, 2007, 2010; Kopacz et al., 2010; Liu et al., 2011), that current $\mathrm{CO}$ emission inventories tend to underestimate source strengths, especially in regions with strong anthropogenic pollution. These findings are confirmed in this study. Beyond this, here we derive $\mathrm{CO}$ concentration profiles, from which information on atmospheric transport patterns can be derived.

We analyse observations of SCanning Imaging Absorption spectroMeter for Atmospheric CHartographY (SCIAMACHY) on board the ENVISAT satellite (Burrows et al., 1995; Bovensmann et al., 1999). Our retrieval of the total atmospheric CO vertical column density (VCD) and its

Published by Copernicus Publications on behalf of the European Geosciences Union. 
validation is described in detail in Liu et al. (2011). Following up on the work of Liu et al. (2011), here we focus on cloud covered pixels with cloud radiance fractions (CRFs) $>30 \%$. The CRF is the fraction of photons received from the cloudy part of the ground pixel compared to the total received radiance (e.g. Veefkind et al., 2006; Joiner et al., 2009); the details of our retrieval are described in Sect. 2. Using mainly cloud-covered observations allows us to apply the so-called cloud slicing technique (CST) (Ziemke et al., 1998, 2001, 2009; Ziemke and Chandra, 1999), based on the assumption that clouds shield absorption by the atmosphere below the cloud top.

Information on effective cloud height and cloud fraction for individual SCIAMACHY CO observations is taken from the $\mathrm{FRESCO}^{+}$algorithm (Fast REtrieval Scheme for Cloud from the Oxygen A band, see Koelemeijer et al., 2001; Wang et al., 2008) derived from the same SCIAMACHY observations (for more details, see Sect. 2.1).

Because of the relatively large uncertainties of the individual SCIAMACHY CO measurements (typically several tens of percent, Frankenberg et al., 2005b; de Laat et al., 2006; Liu et al., 2011) and the relatively low sampling frequency (global coverage after 6 days), the CST can not be applied to individual observations. Instead, averages over rather long periods have to be calculated to achieve meaningful height profiles. In this study seasonal averages over three years (2003-2005) are presented. Our CO profiles have a relatively fine vertical resolution of $1 \mathrm{~km}$, much higher than can be obtained from satellite observations in the thermal IR (see e.g. Drummond and Mand, 1996; Deeter et al., 2003; Rinsland et al., 2006; George et al., 2009; Worden et al., 2010, 2013a; McMillan et al., 2011). It should, however, be noted that especially over land where the surface albedo can reach rather high values (see Sect. 2), a substantial fraction of the measured $\mathrm{CO}$ absorption can originate from the clear part of the ground pixel. In such cases, the vertical resolution of the retrieved profiles is systematically degraded. It should also be noted that the retrieved profiles do not represent actual atmospheric profiles, but complex composites, which combine measurements made under different meteorological conditions. Thus their direct interpretation is difficult and a detailed quantitative interpretation is only possible by comparison with atmospheric models, from which the output is processed according to the same principle. In this study seasonal means of the SCIAMACHY CO profiles are compared to two models: MATCH (Model of Atmospheric Transport and Chemistry, von Kuhlmann et al., 2003) and EMAC (ECHAM5/MESSy Atmospheric Chemistry modelling system, Jöckel et al., 2006). The seasonal means are based on model data sampled at the exact locations and times of the individual SCIAMACHY observations.

The paper is organised as follows: in Sect. 2, we introduce the satellite retrieval and the CST. In Sect. 3 we present and discuss selected comparison results between satellite ob- servations and models. Section 4 provides our summary and conclusions.

\section{Retrieval of atmospheric CO profile information from SCIAMACHY}

In this section we give a brief description of the original $\mathrm{CO}$ retrieval and its modifications used in this study: in the first step, the atmospheric CO VCD is retrieved using the Iterative maximum a posteriori (IMAP)-DOAS method (Frankenberg et al., 2005a, b). In a second step, the CO VCDs are normalised using MOPITT observations over the ocean as described in Liu et al. (2011). The third step differs depending on whether the total CO VCD or CO profiles are retrieved. For the determination of the total CO VCD (Liu et al., 2011), observations for mostly clear sky (effective cloud fraction $<20 \%$ ) are selected and a cloud correction is applied taking into account effective cloud fraction and cloud height. The total CO VCDs for mainly clear-sky observations were validated using ground-based observations, and good agreement (average bias of $-12 \%$, standard deviation of $23 \%$ ) was found. It was shown in Liu et al. (2011) that the agreement between SCIAMACHY and the ground-based stations improved in each of the retrievals steps described above.

In this study, we use observations for (partly) cloudy conditions (CRF > 30\%). In contrast to Liu et al. (2011), no cloud correction is applied. We combine the CO columns with effective cloud fraction and effective cloud height from the $\mathrm{FRESCO}^{+}$algorithm (Koelemeijer et al., 2001; Wang et al., 2008, see also Sect. 2.1).

In the near-infrared fitting range for $\mathrm{CO}(2324 \mathrm{~nm}$ to $2335 \mathrm{~nm}$ ), the wavelength is sufficiently long that Rayleigh scattering can be neglected. Therefore, the photons that the satellite detects are either scattered by clouds and aerosols or reflected at the earth's surface. Within the spectral range, the $\mathrm{CO}$ analysis clouds are not as bright as in the visible spectral range (see e.g. Nakajima and King, 1990), but still brighter than the surface for most of the globe. Thus for most observations the signal from the clouded part contributes the majority of the signal of the measured spectra, which contains information from the atmosphere above the cloud. The dependence of CRF as a function of the effective cloud fraction is shown in Fig. 1 for different values of the surface albedo. In our study we use surface albedo values measured by the MODIS instrument (Justice et al., 1998), see Fig. 2. We consider observations with CRF $>30 \%$ in order to increase the number of useful SCIAMACHY observations.

Since for satellite observations with small CRF a significant part of the information originates from the clear part of the satellite ground pixel (which "sees" the total CO column), the retrieved CO column is systematically larger than the CO column above the cloud. This effect has to be taken into account if the retrieved $\mathrm{CO}$ profiles are compared to other data sets like results from atmospheric models (see Sect. 3). 


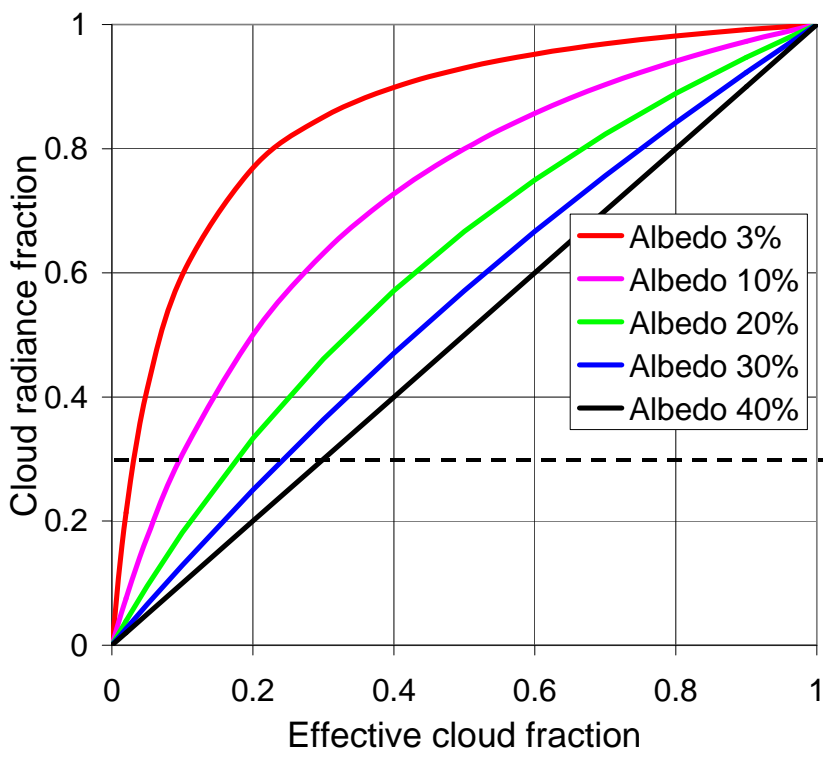

Fig. 1. Dependence of the CRF on the effective cloud fraction for different values of the surface albedo (see also Fig. 2). The black dotted line indicates a CRF of $30 \%$, which is used as threshold value for the $\mathrm{CO}$ measurements from SCIAMACHY in this study.

We apply the CST in the following way: in a first step, the observed CO VCDs are averaged for selected (intervals of) effective cloud heights. Here it should be noted that the effective cloud height from the $\mathrm{FRESCO}^{+}$algorithm systematically underestimates the geometric cloud top height (see Sect. 2.1). Thus here we use the term "effective cloud height". In this study we use intervals of $1 \mathrm{~km}$ from the surface to $9 \mathrm{~km}$ :

$\operatorname{PVCD}_{z_{m}^{*}}=\frac{\sum_{z_{m}<z_{i}<z_{m+1}} \operatorname{VCD}_{z_{i}}}{N}$

Here $z_{m}$ and $z_{m+1}$ are the lower and upper boundary of a selected height interval and $z_{m} *$ is the average cloud height of all observations with cloud heights within that interval. In this study $z_{m} *$ is typically within $z_{m}+0.4 \mathrm{~km}$ and $z_{m}+0.6 \mathrm{~km} . \mathrm{N}$ is the number of all observations used in Eq. (1).

PVCD represents the average partial CO VCD above the respective average effective cloud heights. Global maps of seasonally averaged PVCDs for different cloud heights are presented in Fig. 3. Note that in addition to the clear-sky total CO VCD (Liu et al., 2011), the CO PVCDs retrieved for cloudy satellite pixels also cover the oceans. Especially for low cloud heights, strong spatial gradients are found with the highest values over regions with strong $\mathrm{CO}$ emission sources. Also a strong inter-hemispheric gradient is found. Note that gaps are present especially over deserts because we removed all observations over surfaces with an albedo $>40 \%$. Over highly reflective surfaces cloud algorithms are known to have increased uncertainties. In the maps for low cloud heights gaps are also found over regions with high mountains.

With increasing cloud height, less measurements are available leading to larger scatter or even gaps in the maps of the CO PVCDs. But, as expected the CO PVCDs systematically decrease with altitude. In contrast to the systematic dependence of the CO PVCD on cloud height, the CO PVCDs are almost independent of the selected CRF threshold (see Fig. 4).

From successive pairs of CO PVCDs it is in principle possible to derive the average $\mathrm{CO}$ concentration in the layer between both cloud top altitudes:

$[\mathrm{CO}]_{z_{m} * *}=\frac{\mathrm{PVCD}_{z_{m} *}-\mathrm{PVCD}_{z_{m+1}}}{z_{m} *-z_{m+1} *}$

with $z_{m} * *$ the average of $z_{m} *$ and $z_{m+1} *$.

However, in contrast to the original application of the CST, here we do not determine and discuss such average CO concentration profiles, but focus on profiles of CO PVCDs for three reasons:

a. Despite the fact that large amounts of individual observations are averaged, in some cases the PVCDs are not a smooth function of altitude. This is either caused by "atmospheric noise", or random errors of the measurements. In such cases, concentration profiles as derived from Eq. (2) would show unrealistic oscillations.

b. Since most of the $\mathrm{CO}$ sources are located close to the surface, and the sinks are distributed over a large range of the atmosphere, $\mathrm{CO}$ concentrations (and also PVCDs) are expected to decrease systematically with altitude. Such behaviour is indeed found for most cases. Nevertheless, in some regions, especially in cases of effective convection over strong emission sources, increasing CO PVCDs are found at high altitudes. This is probably caused by the fact that $\mathrm{CO}$ PVCDs from CST for different cloud tops do not represent "average meteorological conditions" and thus not average CO profiles. For such observations, the application of Eq. (2) would lead to negative CO concentrations.

c. Systematic offsets of the CO PVCDs cancel out when applying Eq. (2). Thus information about the absolute values of the CO PVCDs would be lost. The comparison of the model results with satellite and ground-based observations indicates systematic biases for most parts of the globe.

We calculated seasonal averages using measurements over 3 yr (2003-2005). For the comparison with the model data, SCIAMACHY observations are gridded on the model resolution (T42, corresponding to a Gaussian grid of approximately $2.8^{\circ} \times 2.8^{\circ}$ ). 


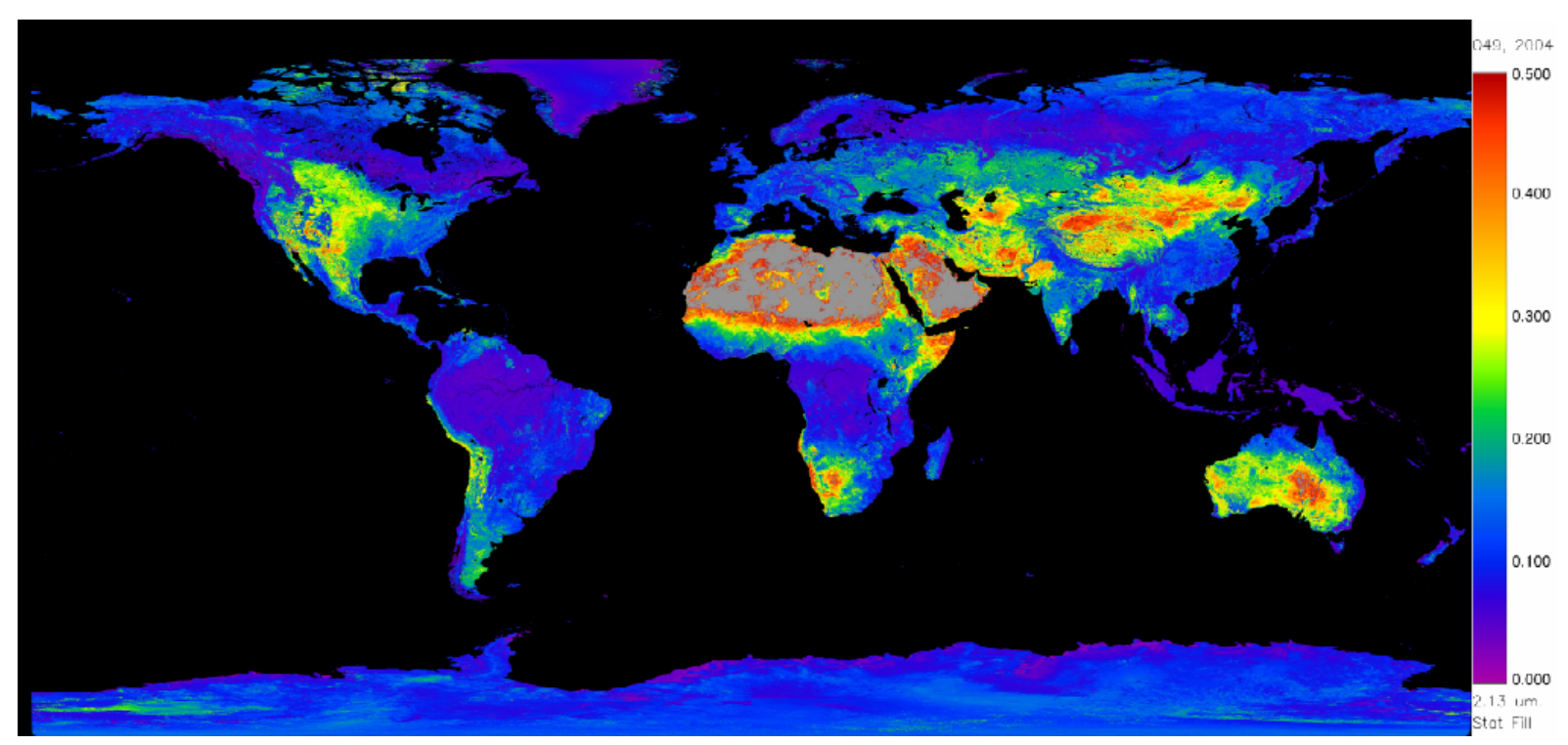

Fig. 2. Global map of the surface albedo at $2130 \mathrm{~nm}$ over the continents from observations of the MODIS instrument (white sky albedo for the first half of March 2004; image from http://modis-atmos.gsfc.nasa.gov/ALBEDO/).

The good agreement of CO PVCDs for different lower thresholds for CRF (Fig. 4) indicates that the exact choice of the threshold is not critical.

Finally, it should again be emphasised that although large numbers of observations were averaged, the atmospheric profiles retrieved by the CST are not per se representative of the actual average atmospheric profiles, since cloud type (and cloud altitude) are systematically correlated to meteorology and atmospheric transport patterns (e.g. convective updraft) and chemistry. Also, the retrieved CO PVCDs systematically overestimate the actual CO PVCD above the cloud because the $\mathrm{CO}$ absorption of the clear part of the satellite pixel substantially contributes to the retrieved CO PVCD. Furthermore, it should again be emphasised that all $\mathrm{CO}$ profiles shown in this study are expressed as PVCDs and not as concentrations or mixing ratios. The retrieved profile information has thus to be interpreted with care. A meaningful quantitative interpretation is only possible by comparison with atmospheric model simulations sampled in the same way as the satellite observations, and taking into account the contributions both from the clear and cloudy part of the satellite pixels, see Sect. 3.

It should also be noted that the CO PVCDs might be affected by spectral interference with the much stronger absorptions of $\mathrm{H}_{2} \mathrm{O}$ and $\mathrm{CH}_{4}$. Therefore, since the absorptions of $\mathrm{H}_{2} \mathrm{O}$ and $\mathrm{CH}_{4}$ systematically depend on cloud altitude, the CO PVCDs might be subject to a systematic bias varying with cloud altitude. Nevertheless, such potential spectral interference can not explain the observed spatial patterns of the CO PVCDs over strong emission sources (see Sects. 3.3 and 3.4).

\subsection{Interpretation of the effective cloud height}

The $\mathrm{FRESCO}^{+}$algorithm used for the determination of the effective cloud height describes clouds as so called Lambertian reflectors (with an assumed albedo of $80 \%$ ) (Koelemeijer et al., 2001). Nevertheless, a significant fraction of the solar photons detected by the satellite instrument may have penetrated into the cloud. Thus they may have encountered stronger $\mathrm{O}_{2}$ absorption than assumed by the Lambertian cloud model and the effective cloud height retrieved by the $\mathrm{FRESCO}^{+}$algorithm would systematically underestimate the true (geometric) cloud top height: on average the $\mathrm{FRESCO}^{+}$cloud height rather represents the middle of the cloud layer than the cloud top (Wang et al., 2008; Sneep et al., 2008). Also at the wavelength used for the $\mathrm{CO}$ analysis $(2330 \mathrm{~nm})$, a fraction of the detected solar photons has penetrated into the cloud leading to systematically higher $\mathrm{CO}$ PVCDs than that for the geometric cloud top height. Compared to the $\mathrm{FRESCO}^{+}$algorithm (at $760 \mathrm{~nm}$ ), the effect is, however, slightly smaller than for the spectral range used for the $\mathrm{CO}$ analysis $(2330 \mathrm{~nm})$, because of the stronger absorption by the cloud droplets (Platnick et al., 2001). Both effects (underestimation of the cloud top height and overestimation of the CO PVCDs) complicate the quantitative comparison between satellite observations and model results, and without detailed information on cloud properties and $\mathrm{CO}$ concentration profiles it is not possible to correct the associated uncertainties for individual observations.

We investigated the differences of the cloud influence in both spectral ranges in more detail by calculating an effective cloud height from the $\mathrm{CH}_{4}$ absorption retrieved in the same fitting window as for the $\mathrm{CO}$ analysis (see also Gloudemans 

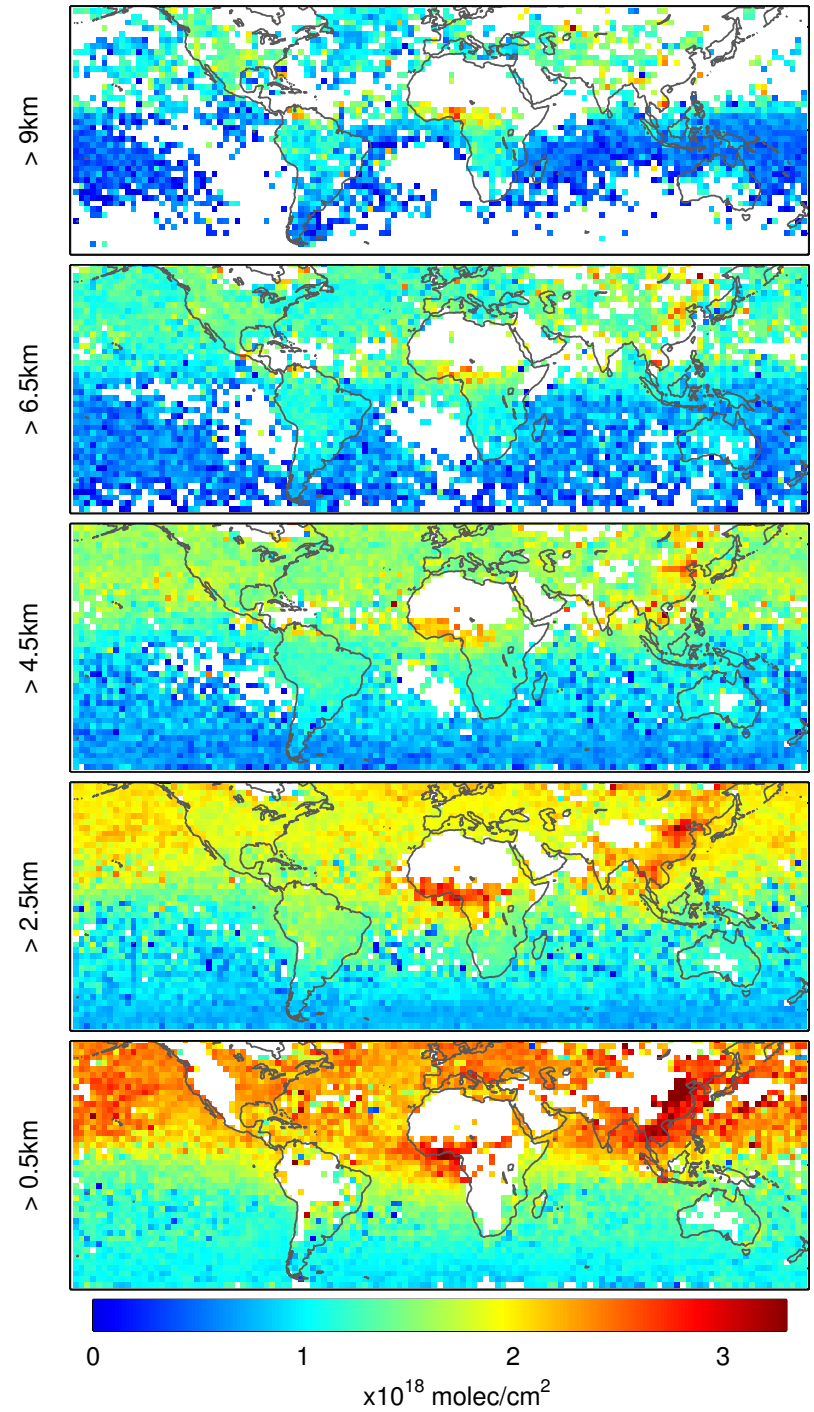

Fig. 3. CO PVCDs for different cloud heights derived from SCIAMACHY measurements from January to March 2003-2005 (measurements with CRF $>30 \%$ ). Gaps are caused by missing measurements or low number of measurements (e.g. over desert regions and high mountains).

et al., 2009). We only considered observations with effective cloud fractions $>80 \%$ to make sure that the contribution from the clear part of the satellite ground pixel can be neglected (see Fig. 1). From the comparison of the retrieved $\mathrm{CH}_{4}$ VCD with the $\mathrm{CH}_{4}$ profile from the US standard atmosphere (scaled by the latitudinal dependent average $\mathrm{CH}_{4}$ VCD for 2004, see Bergamaschi et al., 2009), an effective cloud height for about $2330 \mathrm{~nm}$ is derived. A comparison of the $\mathrm{CH}_{4}$ effective cloud height with the FRESCO effective cloud height (Fig. 5) showed excellent agreement (over ocean: slope $-1.07, r^{2}-0.98$; over land: slope $-1.01, r^{2}$ - 0.93) indicating that differences in the penetration depth of photons into the clouds between both spectral ranges are
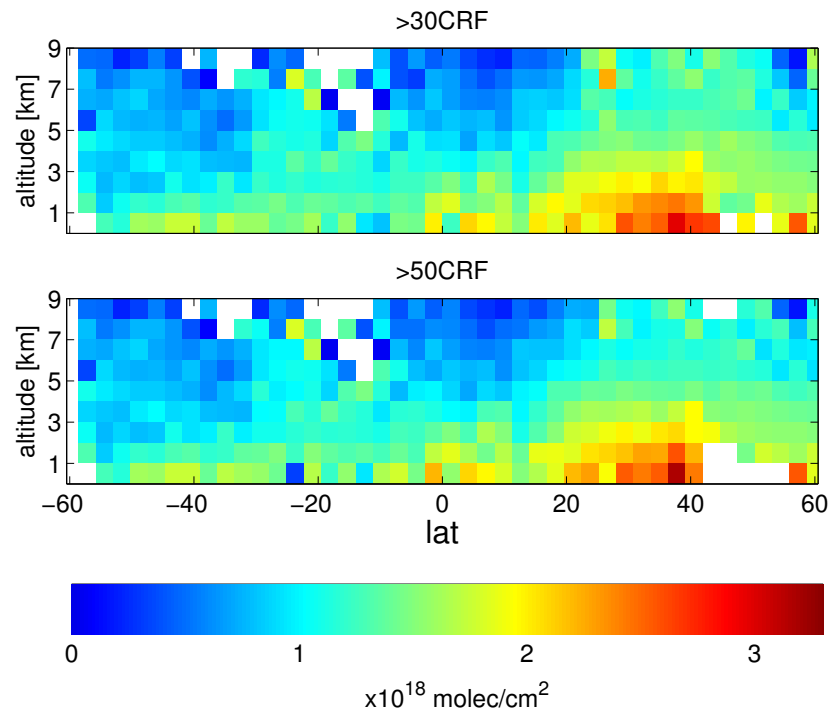

Fig. 4. Example of a meridional cross section of CO PVCDs (averaged over $100^{\circ}$ to $120^{\circ} \mathrm{E}$ for July-September 2003-2005). The spatial patterns and also the absolute values of the PVCDs for the different thresholds of CRF are almost identical. Using more strict selection criteria, for some locations, no measurements are available for certain cloud altitudes. Note that this latitudinal cross section contains both measurements over land (northern part) and ocean (southern part).

small and can be neglected. The slightly smaller slope over land is probably caused by the larger contribution from the clear part of the satellite ground pixels because of the generally higher surface albedo over land. However, because of the selection of measurements with effective cloud fractions $>80 \%$, the influence from the clear part is rather small.

From this finding we conclude that both effects (underestimation of the cloud top height and overestimation of the CO PVCDs) only play a minor role for our study, because in general the (relative) atmospheric $\mathrm{CO}$ concentration profile decreases with altitude, following similar lapse rates as the oxygen concentration. Thus the underestimation of the cloud top height and the overestimation of the CO PVCDs to a large extent compensate. In other words, the retrieved (too low) cloud height fits well to the retrieved (too high) $\mathrm{CO}$ PVCD.

\subsection{Comparison to ground-based observations}

Compared to cloud slicing results for $\mathrm{O}_{3}$ (see e.g. Joiner et al., 2009) validation of our SCIAMACHY CO profiles is a more challenging task. One major problem of SCIAMACHY $\mathrm{CO}$ measurements is that the uncertainties for individual observations are rather large (Frankenberg et al., 2005b; de Laat et al., 2006; Liu et al., 2011), and the sampling frequency is low (global coverage after 6 days). The large uncertainties prevent the meaningful application of individual observations; instead many observations have to be averaged to 

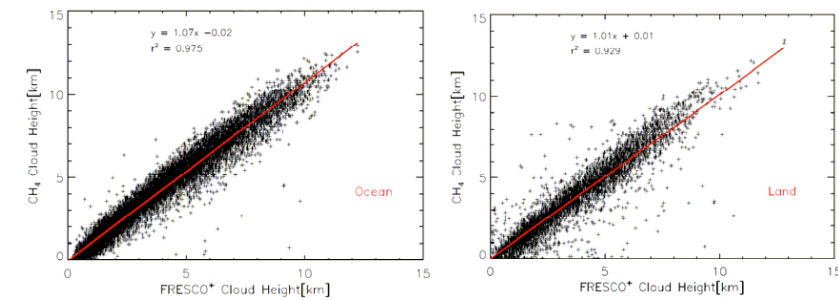

Fig. 5. Comparison of effective cloud height retrieved from the $\mathrm{CH}_{4}$ absorption around $2330 \mathrm{~nm}$ with the effective cloud height retrieved from the $\mathrm{FRESCO}^{+}$algorithm around $760 \mathrm{~nm}$ over ocean (left) and land (right) for January and February 2005.

achieve good signal-to-noise ratios (here we use seasonal averages). Another fundamental problem is that the CO PVCDs for selected effective cloud heights do not represent "average meteorological conditions" and thus not the average CO profile (a comparison of model profiles sampled according to the SCIAMACHY cloud information with the average model profiles is shown in Fig. 9). Thus independent profile information for exactly the selected cloud heights and the corresponding atmospheric conditions would be needed for the validation of CO PVCDs. Such information is not available. Because of these difficulties, no quantitative validation of the SCIAMACHY CO PVCDs for different effective cloud heights is possible.

Instead we compared time series of seasonal averages of the CO PVCDs with total CO VCDs for selected groundbased measurements from the NDACC \& TCCON networks (Wunch et al., 2011) for the years 2003-2005 (Fig. 6). Besides the CO PVCDs for the lowest cloud interval (effective cloud heights $<1 \mathrm{~km}$ ), we also included CO PVCDs for effective cloud heights between $3 \mathrm{~km}$ and $4 \mathrm{~km}$. In addition to the SCIAMACHY CO PVCDs, we also included the coincidently sampled model data in the comparison. For the CO PVCDs $>0.5 \mathrm{~km}$ in general very good agreement between the SCIAMACHY data and the ground-based stations is found, not only for the absolute values but also for the seasonal variation. In contrast to the Northern Hemisphere, in the Southern Hemisphere the SCIAMACHY data slightly overestimate the ground-based measurements.

Furthermore, the modelled concentrations are systematically lower than the ground-based stations, but much smaller differences are found in the Southern Hemisphere. Also in the model data the seasonal variation is well captured.

For clouds between $3 \mathrm{~km}$ and $4 \mathrm{~km}$, no quantitative comparison of the CO PVCDs with the total CO VCDs from the ground-based data is possible (because no information about the CO profile shape is available for the selected stations), but as expected the absolute values are systematically smaller than for the low clouds. Interestingly, the seasonal cycle is still present in the CO PVCDs $>3.5 \mathrm{~km}$.

In Fig. 7 results of a linear regression for the seasonal averages of the CO PVCDs (clouds below $1 \mathrm{~km}$ ) at all sta- tions versus the total $\mathrm{CO} \mathrm{VCD}$ from ground-based station is shown. Good correlation $\left(r^{2}>0.80\right)$ is found between the SCIAMACHY and model data, but the slopes are systematically smaller than unity. Here it is interesting to note that the ratio of the averages (RA) and the averages of the ratios (AR) between all data pairs of the considered data sets are much closer to unity (for the SCIAMACHY data it is almost unity). These findings indicate that the amplitude of the seasonal cycle is probably underestimated by the SCHIAMACHY observations and the model results.

From the comparison with the ground-based observations (Fig. 7), we conclude that the CO PVCDs for effective cloud heights $<1 \mathrm{~km}$ have a systematic bias of $-3 \%$ and a standard deviation of $12 \%$. While the interpretation of the bias is complicated because of the cloud shielding of the lowest part of the atmosphere, the standard deviation can be regarded as representative for the CO PVCDs. Unfortunately, the accuracy of the CO PVCDs for higher cloud altitudes can not be quantified from this validation exercise (and also not from other independent data sets, see above). The uncertainties for such observations are caused by uncertainties in the effective cloud heights (see Fig. 5) and the errors of the CRF (Fig. 1). We estimate these uncertainties by assuming an average $\mathrm{CO}$ profile and average measurement conditions with CRF of $30 \%$ and $60 \%$, respectively (see Table 1). The uncertainties increase with height, but are smaller than the general uncertainties (bias plus scatter) of the $\mathrm{CO}$ retrieval as derived from the comparison of the SCIAMACHY CO PVCDs with the ground-based observations.

\section{Comparison to atmospheric models}

In this section, we compare $\mathrm{CO}$ profiles from SCIAMACHY observations with the results of two atmospheric models (MATCH-MPIC and EMAC). One important aspect of the comparison is that only coincident data are compared: model outputs are sampled at the times and locations of the SCIAMACHY observations taking into account the contributions from the clear an cloudy part of the satellite pixels (according to the CRF, see Sect. 1). Cloud information (CRF and effective cloud height) is taken from the $\mathrm{FRESCO}^{+}$algorithm. We used measured cloud data, because of the rather coarse resolution of the model data. However, since the cloud information is only taken from the SCIAMACHY measurements and not from the models, situations of different meteorological conditions might be compared, potentially introducing systematic biases between the satellite and model data. Fortunately, as shown in the discussion version of our manuscript (Liu et al., 2013), the sampling of the model data according to the measured cloud information from the $\mathrm{FRESCO}^{+}$ algorithm has only negligible influence on the retrieved $\mathrm{CO}$ profiles.

Different from the discussion version of our manuscript (Liu et al., 2013), here the model data were sampled taking 

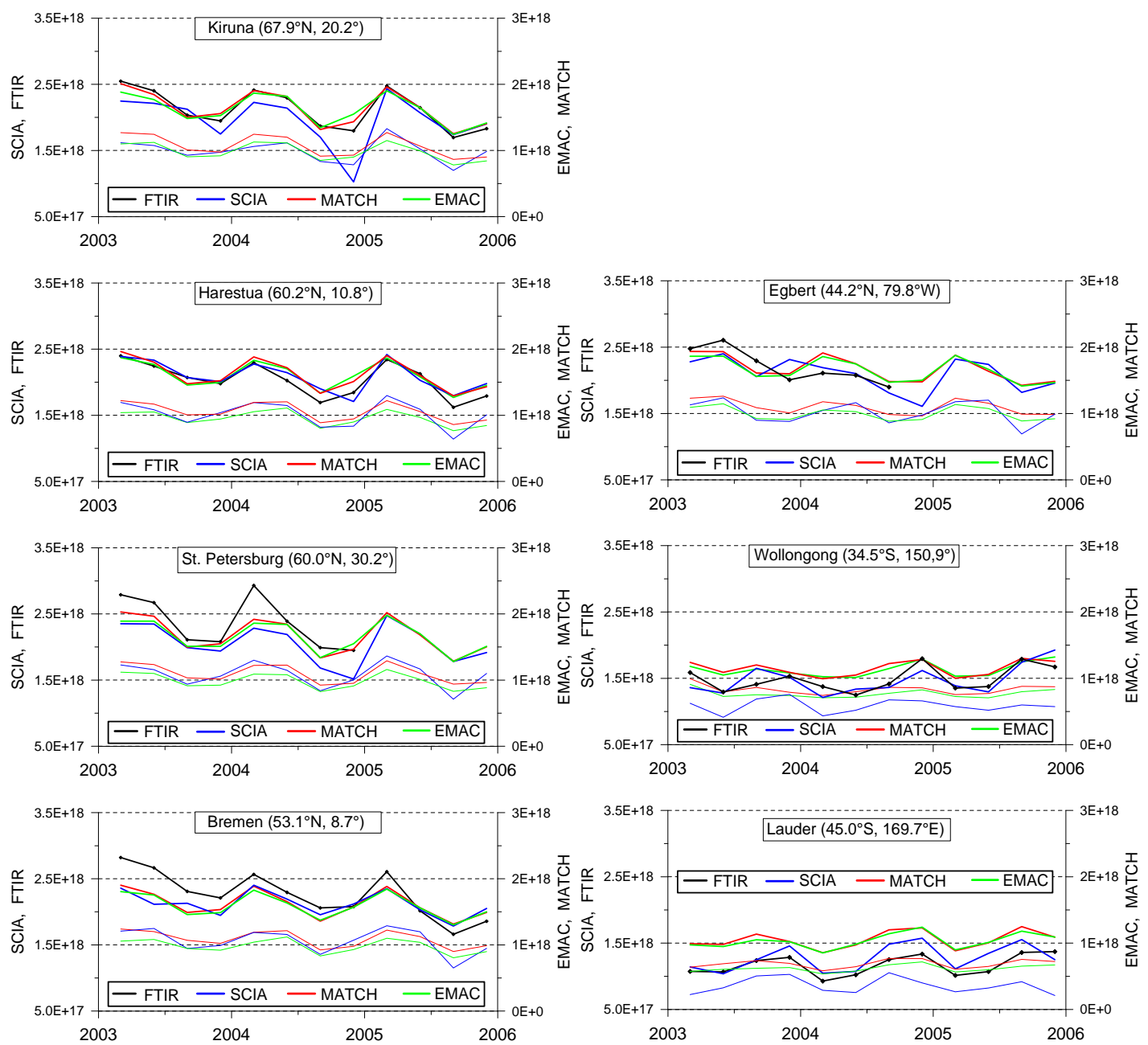

Fig. 6. Comparison of seasonal averages of the CO PVCD from SCIAMACHY and models (coloured lines) with the total CO VCD observed from ground-based FTIR stations (black lines). Thick lines represent CO PVCDs above cloud heights of $0.5 \mathrm{~km}$; thin lines those above $3.5 \mathrm{~km}$. (units: molec $\mathrm{cm}^{-2}$ ). Note different $y$ axes for measurements (left) and model results (right).

Table 1. Typical errors of the CO PVCDs introduced by uncertainties of the effective cloud height and cloud radiance fraction (CRF). Uncertainties are calculated for a measurement with a CRF of $30 \%$ (top) and $60 \%$ (bottom) assuming uncertainties of the surface albedo and cloud top albedo to be about $\pm 5 \%$ (absolute error of the albedo).

\begin{tabular}{lrr}
\hline \multicolumn{3}{c}{ CRF: 30\% } \\
\hline CO PVCD & Error due to uncertainties of the cloud height & Error due to uncertainties of the CRF \\
\hline Above $1 \mathrm{~km}$ & $1 \%$ & $1 \%$ \\
Above $4 \mathrm{~km}$ & $2 \%$ & $6 \%$ \\
Above $9 \mathrm{~km}$ & $3 \%$ & $11 \%$ \\
\hline & CRF: $60 \%$ & \\
\hline CO PVCD & Error due to uncertainties of the cloud height & Error due to uncertainties of the CRF \\
\hline Above $1 \mathrm{~km}$ & $1 \%$ & $1 \%$ \\
Above $4 \mathrm{~km}$ & $3 \%$ & $5 \%$ \\
Above $9 \mathrm{~km}$ & $6 \%$ & $8 \%$ \\
\hline
\end{tabular}




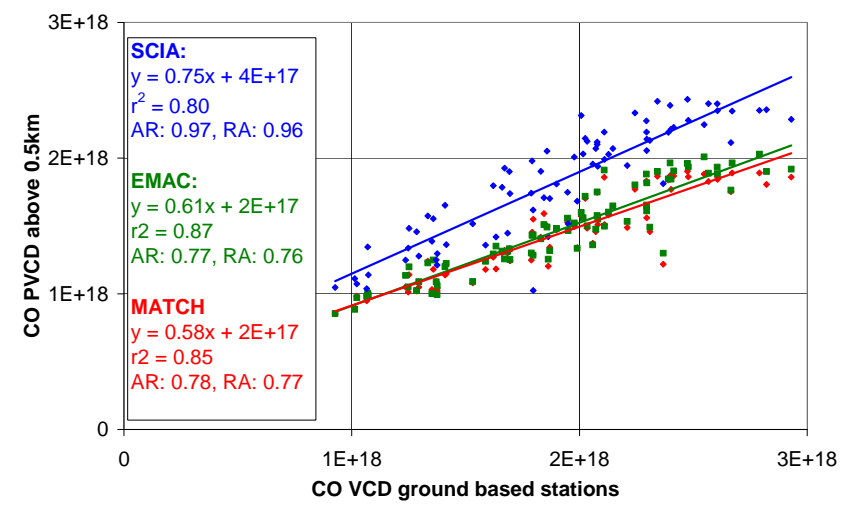

Fig. 7. Correlation analysis of seasonal averages of the CO PVCDs $>0.5 \mathrm{~km}$ vs. total CO VCDs from ground-based FTIR stations. Apart from the SCIAMACHY measurements, the coincident results from both atmospheric models are also shown. In addition to the results of the linear regression, the ratio of the averages (RA) and the average of all ratios (AR) for all data pairs of the considered data sets are also shown.

into account also the contribution from the clear part of the satellite pixels: the average of the total $\mathrm{CO} \mathrm{VCD}$ and the $\mathrm{CO}$ PVCD above the cloud are calculated by weighting the respective contributions according to the CRF and ( 1 - CRF) of the measurement. It should be noted that no averaging kernel is considered for the clear part of the ground pixel, because the shielding effect of clouds dominates the vertical dependence of the measurement sensitivity. It should be noted that for different values of the surface albedo (see Figs. 1 and 2), a CRF corresponds to quite different effective cloud fractions. While over ocean and parts of the continents (e.g. the Amazon region) the surface albedo is only a few percent, in other regions over land, much higher values are found. In Fig. 1 the dependence of the CRF on the effective cloud fraction for different values of the surface albedo is shown.

We compare the derived SCIAMACHY CO profiles to two atmospheric models, which are described in detail in the next sub-sections. Both models are using the same input emissions (for details see below). However, a major difference between the two models is that MATCH-MPIC is a chemistry transport model (CTM), driven by NCEP data, while EMAC is an atmospheric chemistry general circulation model (ACGCM), which for the simulation analysed here was nudged towards ECMWF operational analysis data.

\subsection{MATCH-MPIC}

MATCH-MPIC (Model of Atmospheric Transport and CHemistry - Max Planck Institute for Chemistry version) is a global, three-dimensional chemical transport model representing tropospheric $\mathrm{O}_{3}, \mathrm{CH}_{4}, \mathrm{NO}_{\mathrm{x}}$, and VOC chemistry. MATCH-MPIC has been described and evaluated in detail (Rasch et al., 1997; Lawrence et al., 1999, 2003; von Kuhlmann et al., 2003). MATCH-MPIC is run in a semi- offline mode, relying only on a limited set of input fields (surface pressure, geopotential, temperature, horizontal winds, surface latent and sensible heat fluxes, and zonal and meridional wind stresses). These fields are obtained from the NCEP GFS (National Centers for Environmental Prediction Global Forecast System (Kalnay et al., 1990) and interpolated to the model resolution of T42L42, corresponding to a horizontal resolution of approximately 2.8 by $2.8^{\circ}$, with 42 hybrid pressure-sigma levels in the vertical. Fields are interpolated in time to the model time step of $30 \mathrm{~min}$, and used to diagnose online the transport by advection, vertical diffusion and deep convection, as well as the tropospheric hydrological cycle (water vapour transport, cloud condensate formation and precipitation). The model uses a combination of two convection parameterisations which focus on deep and shallow mixing (Zhang and McFarlane, 1995; Hack, 1994). Anthropogenic emissions are from the Emissions Database for Atmospheric Research (EDGAR) fast track 2000 emissions, which are based on the EDGAR 3.2 emissions inventory (Olivier and Berdowski, 2001). Biomass burning emission data are based on the Global Fire Emissions Database (GFED v2), van der Werf et al. (2006).

\subsection{EMAC}

The ECHAM/MESSy Atmospheric Chemistry (EMAC) model is a numerical chemistry and climate simulation system that includes sub-models describing tropospheric and middle atmosphere processes and their interaction with oceans, land and human influences (Jöckel et al., 2010). It uses the Modular Earth Sub-model System (MESSy, version 2.3; Jöckel et al., 2005) to link multi-institutional computer codes. The core atmospheric model is the 5th generation European Centre Hamburg general circulation model (ECHAM version 5.3.02, Röckner et al., 2006). For the present study we applied EMAC in the T42L90MA-resolution, that is, with a spherical truncation of T42 (corresponding to a quadratic Gaussian grid of approx. $2.8^{\circ}$ by $2.8^{\circ}$ in latitude and longitude) with 90 vertical hybrid pressure levels up to $0.01 \mathrm{hPa}$ (middle atmosphere). As in MATCH-MPIC, in the EMAC set-up the biomass burning emissions are taken from the Global Fire Emission Database (GFED v2) (van der Werf et al., 2006), and the anthropogenic emissions from the EDGAR3.2FT2000 (Pozzer et al., 2009; Tost et al., 2010).

Model output for analysis was triggered every $5 \mathrm{~h}$ of simulation time. For EMAC, the prognostic variables vorticity, divergence, temperature and the (logarithm of the) surface pressure have been nudged to the operational ECMWF analysis data in order to allow a point-to-point comparison to the satellite data (see Jöckel et al., 2010). Primary emissions and dry deposition of trace gases and aerosols were calculated with the sub-models ONLEM, OFFLEM, TNUDGE (Kerkweg et al., 2006a), and DRYDEP (Kerkweg et al, 2006b), respectively. EMAC parameterise convection following Tiedtke (1989) and Nordeng (1994) for both 
deep and shallow convection. More details on the overall model set-up (including emissions) are presented by Jöckel et al. (2006, 2010) and Pozzer et al. (2007).

$\mathrm{CO}$ results from the EMAC model have been extensively compared to aircraft measurements and especially over the Northern Hemisphere often lower CO concentrations compared to the in situ measurements were found (see Supplement in Jöckel et al. (2010), http://www.geosci-model-dev. net/3/717/2010/gmd-3-717-2010-supplement.zip.).

\subsection{Comparison of height profiles for selected regions}

In this section we quantitatively compare the measured $\mathrm{CO}$ profiles (PVCDs) for different regions (see Fig. 8). The selected regions either represent clean oceanic regions remote from strong emission sources or areas with strong $\mathrm{CO}$ emissions caused, for example, by biomass burning or anthropogenic activities related to industry, traffic and energy use. In addition, we also consider observations over the continents, but outside regions with strong emission sources. Figure 9 presents seasonally averaged profiles of the CO PVCDs derived from SCIAMACHY observations and the MATCH and EMAC models. Note that in addition to the average model profiles (using the SCIAMACHY cloud selection criterion, see Sect. 2) also average EMAC CO profiles based on all model profiles without cloud slicing are shown (dark green). From the comparison of the model profiles with and without cloud slicing, the influence of the clear part of the satellite ground pixels to the retrieved CO PVCDs becomes obvious. Especially for polluted regions over the continents, the CO PVCDs using cloud slicing are systematically larger than without cloud slicing. This indicates that in such cases the high total CO VCD observed in the clear part of the satellite pixel contributes significantly to the average CO PVCD of the complete satellite pixel. Nevertheless, over oceans model results with and without cloud slicing are very similar, because the surface albedo over the ocean is much smaller than over the continents.

In the following we compare the SCIAMACHY CO profiles with the coincident model results sampled according to the effective cloud height and the CRF as described above. The columns in Fig. 9 show data for January-March, AprilJune, July-September, and October-December as well as annual mean values. In Fig. 10, the respective relative differences are presented. In general, the SCIAMACHY derived PVCDs are higher, particularly in the Northern Hemisphere. The reason for these differences is not completely clear, but similar latitudinally dependent differences between satellite observations (SCIAMACHY and MOPITT, AIRS, TES, IASI) and model results were also reported in other studies (e.g. Shindell et al., 2006; Gloudemans et al., 2009, De Laat et al., 2010; Kopacz et al., 2010; Liu et al., 2010; Klonecki et al., 2012; Pechony et al., 2013; Worden et al., 2013b). Note that the GFEDv2 emissions used in both the EMAC and MATCH-MPIC model are in the lower range of the lit-

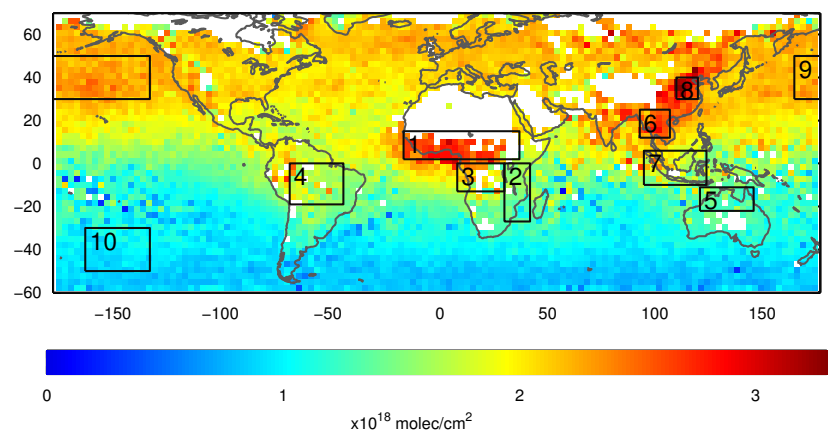

Fig. 8. Mean CO PVCDs (units: molec $\mathrm{cm}^{-2}$ ) retrieved from SCIAMACHY (January to March 2003-2005) for CRF > 30\% and $1 \mathrm{~km}$ $<$ cloud height $<2 \mathrm{~km}$. The boxes indicate regions that are selected for quantitative comparison between SCIAMACHY observations and model simulations.

erature (see e.g. Pozzer et al., 2007). Also Liu et al. (2011) found larger differences between SCIAMACHY and models in the Northern Hemisphere (for mainly cloud-free observations over land surfaces). Here it is interesting to note that also the comparison of the model data to ground-based FTIR stations (see Sect. 2.2) indicates that the underestimation of the model simulations is smaller in the Southern Hemisphere.

Interestingly, the differences between the SCIAMACHY profiles and those from MATCH-MPIC and EMAC stay rather constant between $0.5 \mathrm{~km}$ and $8.5 \mathrm{~km}$ for most regions. Over the Southern Ocean, however, the differences increase systematically with altitude. In general, the differences between MATCH-MPIC and SCIAMACHY are smaller than those between EMAC and SCIAMACHY, and the differences between EMAC and SCIAMACHY usually increase more strongly with altitude. These findings probably indicate differences of the convection schemes (Tost et al., 2006) and wind fields used in both models (see Sects. 3.1 and 3.2).

The first four rows in Fig. 9 present profile comparisons over polluted continental regions. Over China (region 8 in Fig. 8), the satellite profiles show systematically larger values than the models, in agreement with other studies (e.g. Liu et al., 2011, and references therein). These differences are almost constant with altitude and largest for winter and spring.

In other regions, which are seasonally polluted by biomass burning (regions 1, 3, 4, three upper rows in Fig. 9), the SCIAMACHY PVCDs are also systematically larger than the model profiles during the biomass burning seasons, but compared to China, the differences are usually smaller. Over biomass burning regions, EMAC simulations usually show larger differences to SCIAMACHY than MATCH-MPIC.

Interestingly, for the seasons without biomass burning, the differences between SCIAMACHY observations and the models are often smaller than over the remote ocean. 


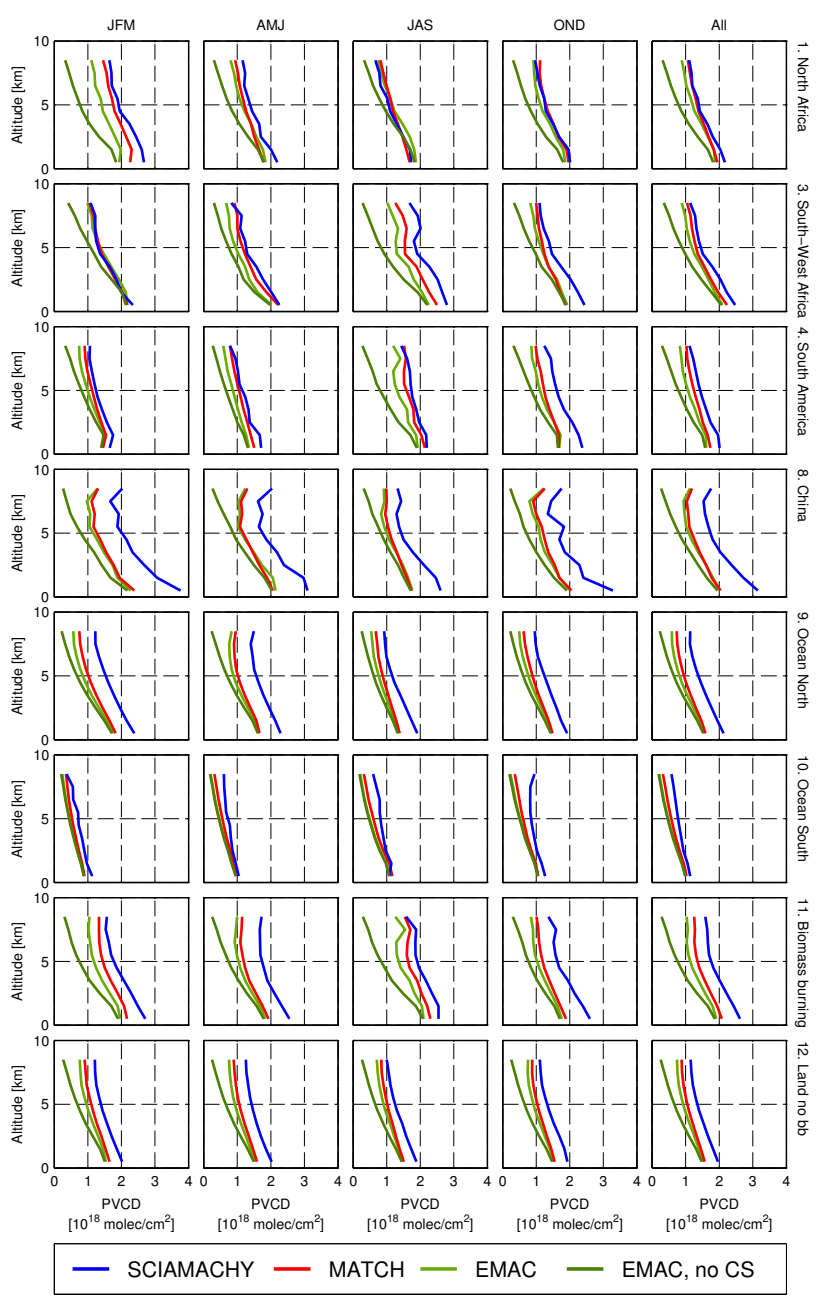

Fig. 9. Comparison of seasonally and annually averaged profiles of CO PVCDs from SCIAMACHY observations and model simulations for selected regions (see Fig. 8). In addition to results for the selected regions, also average results for biomass burning regions (second row from bottom) and for observations over continents far away from strong emission sources (total CO VCD $<2.8 \cdot 10^{18}$ molec $\mathrm{cm}^{-2}$ ) (bottom row) are shown. The dark green lines indicate EMAC results without cloud slicing (see text).

Additional comparisons of $\mathrm{CO}$ profiles from SCIAMACHY observations and model simulations (for regions 2, 5,6 , and 7) are presented in the Supplement.

\subsection{Comparison of latitude/longitude-height cross sections}

In this section we compare latitudinal-height and longitudinal-height cross sections of CO PVCDs derived from SCIAMACHY observations and models. Such comparisons allow the study of the horizontal variation of the $\mathrm{CO}$ profiles and can thus yield information about potential processes causing differences between measured and simulated $\mathrm{CO}$ profiles.

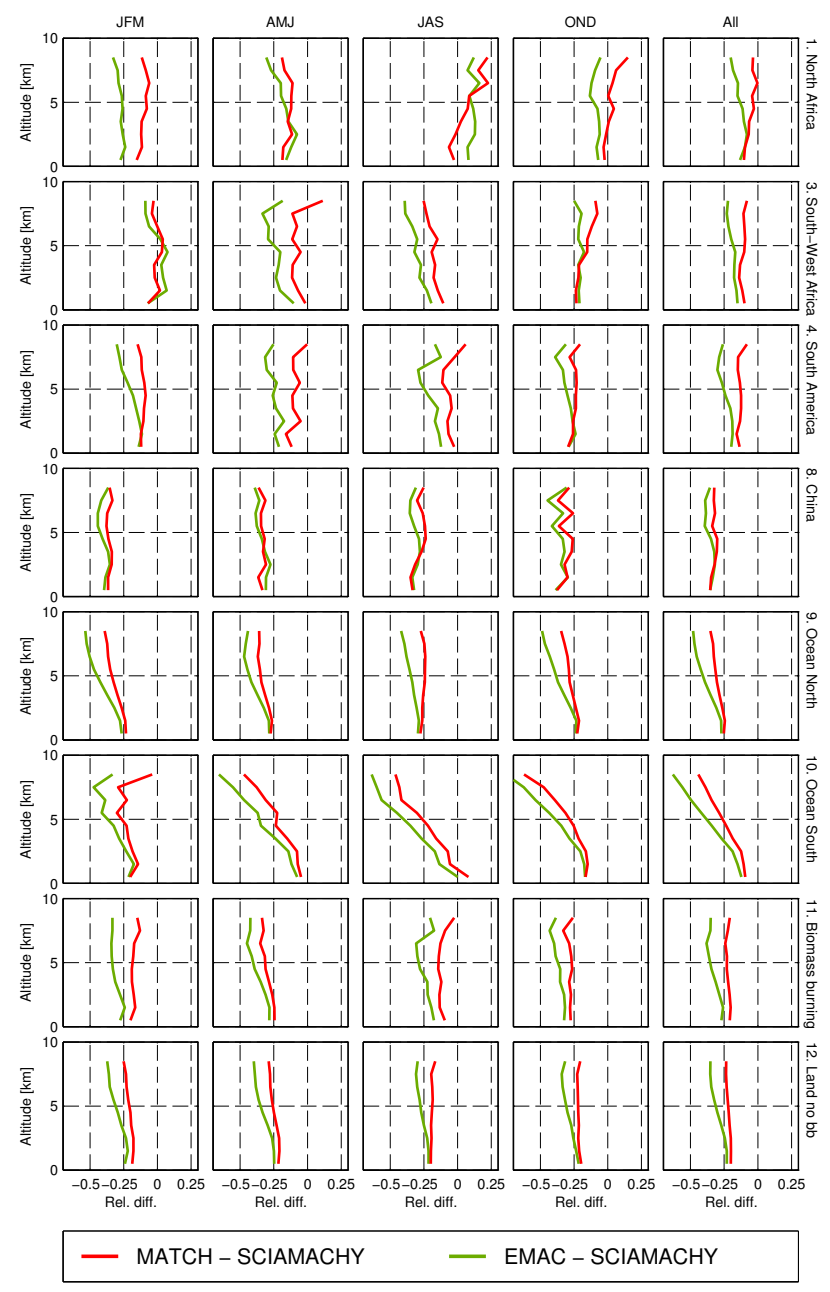

Fig. 10. Relative differences ( $\left.\frac{\text { model-SCIAMACHY }}{\text { SCIAMACHY }}\right)$ for all regions shown in Fig. 9.

Zonal and meridional cross sections are calculated from CO PVCDs over latitude/longitude intervals of $20^{\circ}$ (seven zonal cross sections from $80^{\circ} \mathrm{N}$ to $60^{\circ} \mathrm{S}, 18$ meridional cross sections from $180^{\circ} \mathrm{W}$ to $180^{\circ} \mathrm{E}$ ) for each season. Thus in total, 100 cross sections are calculated, which are all presented in the Supplement. In general, very good agreement of the spatial patterns is found, while the absolute values are systematically smaller in the models.

In the following, we show seven selected cross sections (Figs. 11-13) representing cases with strong pollution caused by anthropogenic activities or biomass burning.

It should be noted that the colour scales are different for SCIAMACHY observations and models to account for the systematic differences of both data sets (shifted by $5 \cdot 10^{17}$ molec cm $^{-2}$ ).

The first example (Fig. 11) shows meridional and zonal cross sections for January to March over China. Also presented in Fig. 11 is the global map of the total (cloud free) CO VCD for the same season (from Liu et al., 2011). A strong 

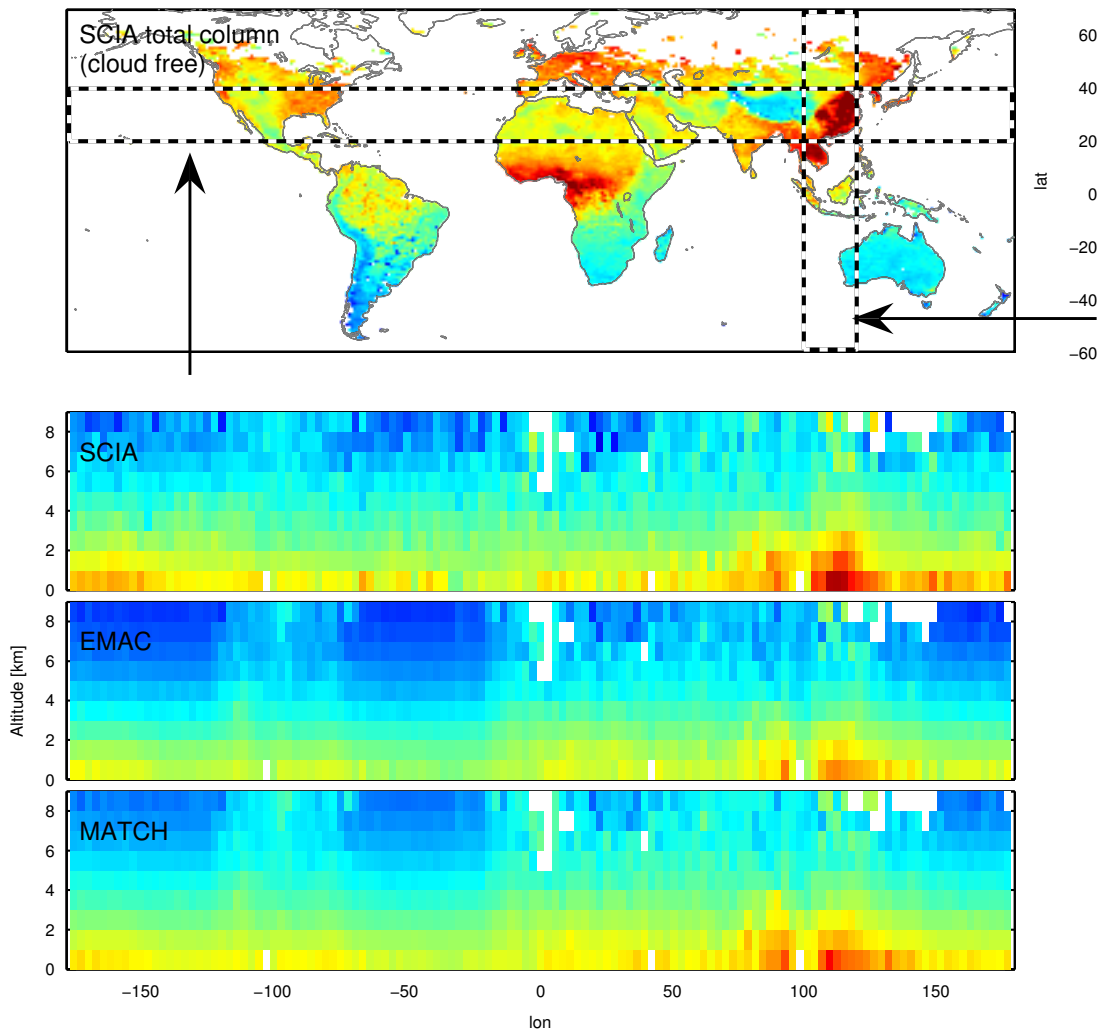
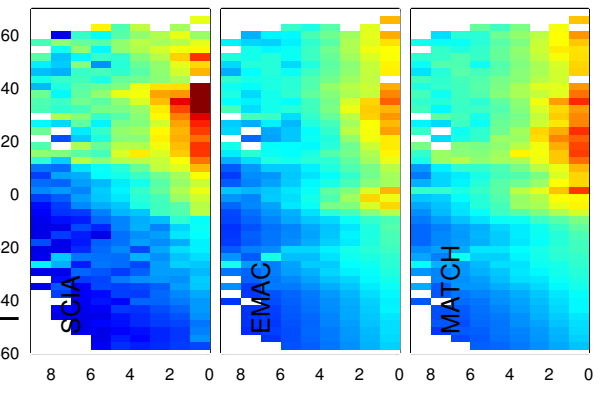

Altitude $[\mathrm{km}]$

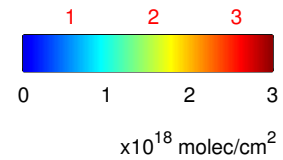

Fig. 11. Top left: global distribution of the total CO VCD for January-March derived from mainly clear-sky SCIAMACHY observations (Liu et al., 2011). Top right: meridional cross sections of profiles of CO PVCDs (for CRF > $30 \%$ ) for the same season derived from SCIAMACHY observations and model simulations. Bottom: zonal cross sections of profiles of CO PVCDs for the same season derived from SCIAMACHY observations and model simulations. Note that the colour scale is different for satellite observations and models (SCIAMACHY: red numbers on top of colour bar; models: black numbers below colour bar).

increase of the CO columns is found over China, both in the SCIAMACHY observations and model results. The spatial patterns in both cross sections are very similar for the SCIAMACHY observations and the model simulations, but the absolute values differ largely throughout the troposphere (see also Fig. 9), indicating that the source strengths in the emission inventories are probably underestimated.

Figure 12 shows cross sections for January to March over biomass burning regions in Africa. As for the cross sections above China, similar spatial patterns are found in the SCIAMACHY and model data. SCIAMACHY and model data not only indicate effective upward transport, but also a tilt of the biomass burning "plume" in the meridional cross section. In (northern) winter the plume is inclined towards the north, because the inner tropical convergence zone (ITCZ) is located south of the biomass burning region.

Good agreement of the spatial patterns is also found in cross sections for July to September in biomass burning regions in Africa and South America (Fig. 13). A slight tilt towards the south occurs in the biomass burning plumes over both regions, which corresponds to a northerly location of the ITCZ in this season. Interestingly a tilt is also found in the zonal cross section.

Like for China, systematic differences between SCIAMACHY and the model results are found throughout the troposphere (see also Fig. 9) indicating that the source strengths in the biomass burning emissions are probably underestimated. But in contrast to China, the differences between EMAC and SCIAMACHY over biomass burning regions are in general larger than those between MATCH-MPIC and SCIAMACHY, and these differences increase with altitude. Both findings probably indicate the effects of the different convection schemes used in both models.

\section{Summary and conclusions}

We apply the cloud slicing technique (CST) to CO vertical column densities retrieved from the Scanning Imaging Absorption spectrometer for Atmospheric CHartographY (SCIAMACHY) for 2003-2005. Our CO profiles range from $0.5 \mathrm{~km}$ to $9.5 \mathrm{~km}$ and have a vertical resolution of $1 \mathrm{~km}$, which is much higher compared to other satellite $\mathrm{CO}$ data sets (e.g. retrieved in the thermal IR). However, with the CST 

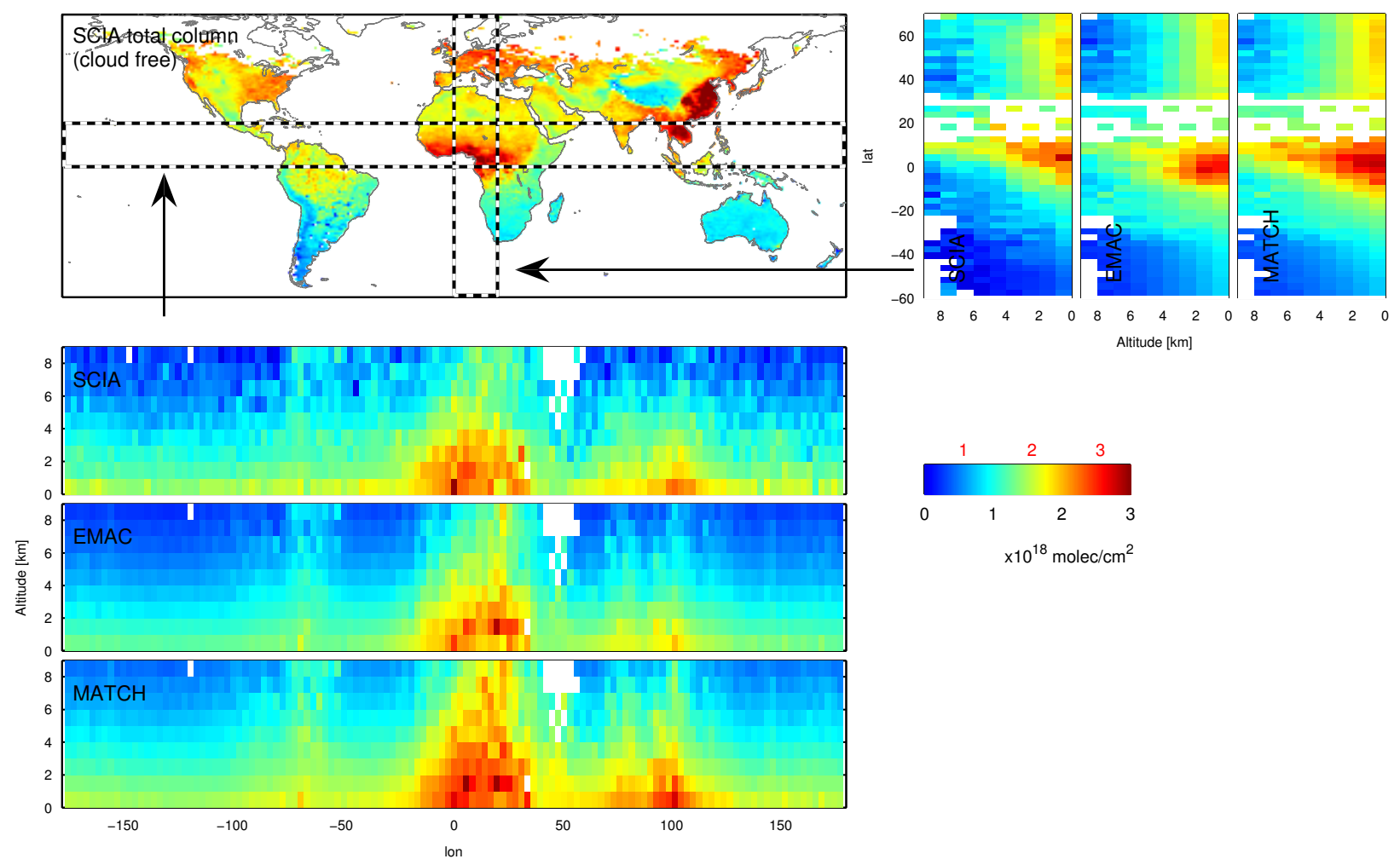

Fig. 12. Same as Fig. 11, but for meridional and zonal cross sections (January-March) over Africa.

it is not possible to retrieve $\mathrm{CO}$ profiles for individual observations, but instead large data sets have to be averaged (here we use seasonal averages for the years 2003-2005). It should also be noted that especially over land where the surface albedo can reach rather high values (see Sect. 2), a substantial fraction of the measured $\mathrm{CO}$ absorption can originate from the clear part of the ground pixel. In such cases, the vertical resolution of the retrieved profiles is systematically degraded. Furthermore, since both the atmospheric $\mathrm{CO}$ profiles and the effective cloud heights depend systematically on meteorology, the retrieved average CO profiles do not represent exact profiles and have to be interpreted with care. For the same reason, we determine profiles of the partial CO column densities instead of the $\mathrm{CO}$ concentrations: in some cases the partial CO column densities for higher cloud altitudes are larger than for lower cloud altitudes which would cause negative $\mathrm{CO}$ concentrations if simple differences are formed. It should also be noted that the height of the retrieved $\mathrm{CO}$ profiles does not exactly match the actual geometric height, because a substantial fraction of the retrieved CO PVCD originates from the clear part of the satellite pixel. But this effect does not influence the comparison with the model results, because the model data are sampled taking the contribution from the clear part into account.

We compare the SCIAMACHY CO profiles with two atmospheric models (MATCH-MPIC and EMAC). In general we find good agreement of the spatial patterns between measurements and model results. Systematic differences are found for the absolute values, especially in the Northern Hemisphere, for which we have no clear explanation. Such differences were, however, also found in other studies (e.g. Shindell et al., 2006; Gloudemans et al., 2006, 2009; De Laat et al., 2006, 2007, 2010; Kopacz et al., 2010; Liu et al., 2010, 2011; Klonecki et al., 2012; Pechony et al., 2013; Worden et al., 2013b), and are probably related to uncertainties of the used emission inventories in addition to uncertainties of the $\mathrm{CO}$ measurements. Here it is interesting to note that also the comparison of the model data to ground-based FTIR stations indicates a smaller underestimation of the model results in the Southern Hemisphere. The observed differences stay rather constant throughout the troposphere for most regions. One exception, however, is the Southern Ocean, where the differences increase systematically with altitude.

We investigated the spatial patterns in more detail for selected regions with strong air pollution: over China and over biomass burning regions in Africa and South America, similar spatial patterns are found in SCIAMACHY and model data indicating that overall the used convection schemes are well suited to describe the uplift of air masses with enhanced $\mathrm{CO}$ concentrations. With respect to the absolute values, our finding is like for the general regions, namely that the modeled concentrations are systematically smaller than the SCIAMACHY observations indicating an underestimation of the $\mathrm{CO}$ source strengths in the emission inventories. 


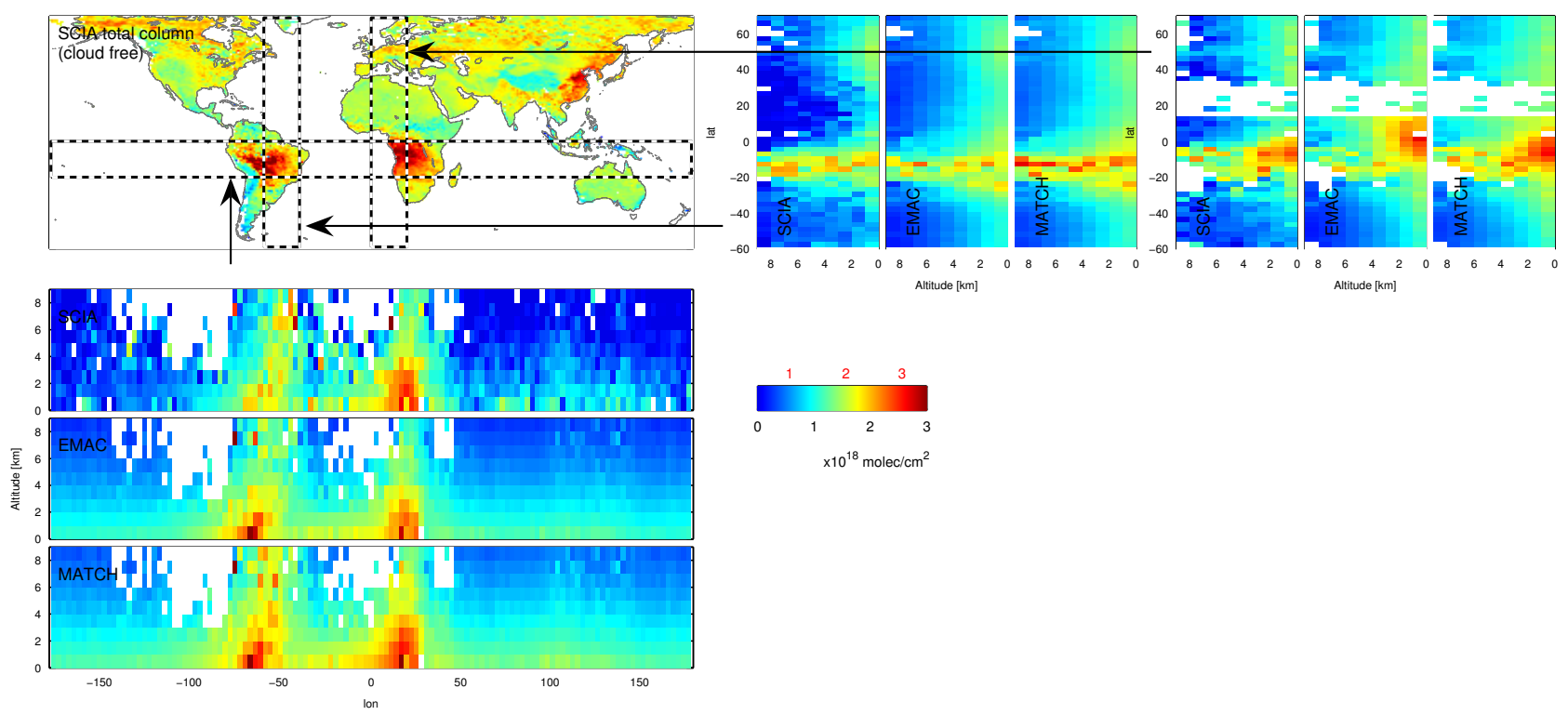

Fig. 13. Same as Fig. 11, but for July-September and for meridional and zonal cross sections over Africa and South America.

However, while over China both models show very similar results, the differences between EMAC and SCIAMACHY over biomass burning regions are in general larger than those between MATCH-MPIC and SCIAMACHY and also increase with altitude. These findings point to the significance of differences in the vertical resolution and the way transport is treated in the models (see Sects. 3.1 and 3.2).

Similar studies using the CST for satellite observations of $\mathrm{CO}$ might also be performed for other sensors, for example, for the near-IR and thermal IR channels from MOPITT, or other nadir-looking IR instruments such as TES or IASI. The CO CST will particularly be interesting for the upcoming SENTINEL missions. The SCIAMACHY CO profiles can be made available on request.

\section{Supplementary material related to this article is available online at http://www.atmos-chem-phys.net/14/ 1717/2014/acp-14-1717-2014-supplement.pdf.}

Acknowledgements. We like to thank the European Space Agency (ESA) operation center in Frascati (Italy) for making the SCIAMACHY spectral data available. FRESCO $^{+}$cloud data were obtained from Tropospheric Emission Monitoring Internet Service, http://www.temis.nl/fresco/. This work was supported by the National Natural Science Funds of China (grant no. 41105011). TCCON data were obtained from the TCCON Data Archive, operated by the California Institute of Technology from the website at http://tccon.ipac.caltech.edu/ (Wunch et al., 2011). Additional FTIR data used in this publication were obtained as part of the Network for the Detection of Atmospheric Composition Change (NDACC) and are publicly available (see http://www.ndacc.org). MODIS albedo data were obtained from NASA's Earth Observing
System (EOS), http://modis-atmos.gsfc.nasa.gov/ALBEDO/. We thank J. de Laat for his help in getting access to additional FTIR data.

The service charges for this open access publication have been covered by the Max Planck Society.

Edited by: C. Gerbig

\section{References}

Bergamaschi, P., Frankenberg, C., Meirink, J. F., Krol, M., Villani, G., Houweling, S., Dentener, F., Dlugokencky, E. J., Miller, J. B., Gatti, L. V., Engel, A., and Levin, I.: Inverse modeling of global and regional $\mathrm{CH}_{4}$ emissions using SCIAMACHY satellite retrievals, J. Geophys. Res., 114, D22301, doi:10.1029/2009JD012287, 2009.

Bovensmann, H., Burrows, J. P., Buchwitz, M., Frerick, J., Noel, S., Rozanov, V. V., Chance, K. V., and Goede, A. P. H.: SCIAMACHY: Mission objectives and measurement modes, J. Atmos. Sci., 56, 127-150, 1999.

Burrows, J. P., Hoelzle, E., Goede, A. P. H., Visser, H., and Fricke, W.: Sciamachy - Scanning Imaging Absorption Spectrometer for Atmospheric Chartography, Acta Astronaut., 35, 445-451, 1995.

Cicerone, R. J.: How has the Atmospheric Concentration of $\mathrm{CO}$ changed, in: The Changing Atmosphere, edited by: Rowland, F. S. and Isaksen, I. S. A., John Wiley \& Sons, New York, 1988.

Crutzen P. J. and Gidel, L. T.: A two-dimensional photochemical model of the atmosphere. 2: The tropospheric budgets of anthropogenic chlorocarbons $\mathrm{CO}, \mathrm{CH}_{4}, \mathrm{CH}_{3} \mathrm{Cl}$ and the effect of various. $\mathrm{NO}_{\mathrm{x}}$ sources on tropospheric ozone, J. Geophys. Res., 88, 6641-6661, 1983.

Deeter, M. N., Emmons, L. K., Francis, G. L., Edwards, D. P., Gille, J. C., Warner, J. X., Khattatov, B., Ziskin, D., Lamarque, J. F., Ho, S. P., Yudin, V., Attie, J. L., Packman, D., Chen, J., Mao, D., 
and Drummond, J. R.: Operational carbon monoxide retrieval algorithm and selected results for the MOPITT instrument, J. Geophys. Res.-Atmos., 108, 4399, doi:10.1029/2002jd003186, 2003. de Laat, A. T. J., Gloudemans, A. M. S., Schrijver, H., van den Broek, M. M. P., Meirink, J. F., Aben, I., and Krol, M.: Quantitative analysis of SCIAMACHY carbon monoxide total column measurements, Geophys. Res. Lett., 33, L07807, doi:10.1029/2005g1025530, 2006.

de Laat, A. T. J., Gloudemans, A. M. S., Aben, I., Krol, M., Meirink, J. F., van der Werf, G. R., and Schrijver, H.: Scanning Imaging Absorption Spectrometer for Atmospheric Chartography carbon monoxide total columns: Statistical evaluation and comparison with chemistry transport model results, J. Geophys. Res.-Atmos., 112, D21306, doi:10.1029/2007jd009378, 2007.

de Laat, A. T. J., Gloudemans, A. M. S., Aben, I., and Schrijver, H.: Global evaluation of SCIAMACHY and MOPITT carbon monoxide column differences for 2004-2005, J. Geophys. Res.Atmos., 115, D06307, doi:10.1029/2009jd012698, 2010.

Drummond, J. R. and Mand, G. S.: The measurements of pollution in the troposphere (MOPITT) instrument: Overall performance and calibration requirements, J. Atmos. Ocean. Tech., 13, 314320, 1996.

Frankenberg, C., Platt, U., and Wagner, T.: Iterative maximum a posteriori (IMAP)-DOAS for retrieval of strongly absorbing trace gases: Model studies for $\mathrm{CH}_{4}$ and $\mathrm{CO}_{2}$ retrieval from near infrared spectra of SCIAMACHY onboard ENVISAT, Atmos. Chem. Phys., 5, 9-22, doi:10.5194/acp-5-9-2005, 2005a.

Frankenberg, C., Platt, U., and Wagner, T.: Retrieval of CO from SCIAMACHY onboard ENVISAT: detection of strongly polluted areas and seasonal patterns in global CO abundances, Atmos. Chem. Phys., 5, 1639-1644, doi:10.5194/acp-5-1639-2005, 2005 b.

George, M., Clerbaux, C., Hurtmans, D., Turquety, S., Coheur, P.F., Pommier, M., Hadji-Lazaro, J., Edwards, D. P., Worden, H., Luo, M., Rinsland, C., and McMillan, W.: Carbon monoxide distributions from the IASI/METOP mission: evaluation with other space-borne remote sensors, Atmos. Chem. Phys., 9, 8317-8330, doi:10.5194/acp-9-8317-2009, 2009.

Gloudemans, A. M. S., Krol, M. C., Meirink, J. F., de Laat, A. T. J., van der Werf, G. R., Schrijver, H., van den Broek, M. M. P., and Aben, I.: Evidence for long-range transport of carbon monoxide in the Southern Hemisphere from SCIAMACHY observations, Geophys. Res. Lett., 33, L16807, doi:10.1029/2006g1026804, 2006.

Gloudemans, A. M. S., de Laat, A. T. J., Schrijver, H., Aben, I., Meirink, J. F., and van der Werf, G. R.: SCIAMACHY CO over land and oceans: 2003-2007 interannual variability, Atmos. Chem. Phys., 9, 3799-3813, doi:10.5194/acp-9-3799-2009, 2009.

Hack, J. J.: Parameterization of moist convection in the National Center for Atmospheric Research Community Climate Model (CCM2), J. Geophys. Res., 99, 5551-5568, 1994.

Jöckel, P., Sander, R., Kerkweg, A., Tost, H., and Lelieveld, J.: Technical Note: The Modular Earth Submodel System (MESSy) - a new approach towards Earth System Modeling, Atmos. Chem. Phys., 5, 433-444, doi:10.5194/acp-5-433-2005, 2005.

Jöckel, P., Tost, H., Pozzer, A., Brühl, C., Buchholz, J., Ganzeveld, L., Hoor, P., Kerkweg, A., Lawrence, M. G., Sander, R., Steil, B., Stiller, G., Tanarhte, M., Taraborrelli, D., van Aardenne, J., and Lelieveld, J.: The atmospheric chemistry general circulation model ECHAM5/MESSy1: consistent simulation of ozone from the surface to the mesosphere, Atmos. Chem. Phys., 6, 50675104, doi:10.5194/acp-6-5067-2006, 2006.

Jöckel, P., Kerkweg, A., Pozzer, A., Sander, R., Tost, H., Riede, H., Baumgaertner, A., Gromov, S., and Kern, B.: Development cycle 2 of the Modular Earth Submodel System (MESSy2), Geosci. Model Dev., 3, 717-752, doi:10.5194/gmd-3-717-2010, 2010.

Joiner, J., Schoeberl, M. R., Vasilkov, A. P., Oreopoulos, L., Platnick, S., Livesey, N. J., and Levelt, P. F.: Accurate satellitederived estimates of the tropospheric ozone impact on the global radiation budget, Atmos. Chem. Phys., 9, 4447-4465, doi:10.5194/acp-9-4447-2009, 2009.

Justice, C. O., Vermote, E., Townshend, J. R. G., Defries, R., Roy, D. P., Hall, D. K., Salomonson, V. V., Privette, J. L., Riggs, G., Strahler, A., Lucht, W., Myneni, R. B., Knyazikhin, Y., Running, S. W., Nemani, R. R., Wan, Z. M., Huete, A. R., van Leeuwen, W., Wolfe, R. E., Giglio, L., Muller, J. P., Lewis, P., and Barnsley, M. J.: The Moderate Resolution Imaging Spectroradiometer (MODIS): Land remote sensing for global change research, IEEE T. Geosci. Remote, 36, 1228-1249, 1998

Kalnay, E., Kanamitsu, M., and Baker, W. E.: Global Numerical Weather Prediction at the National-Meteorological-Center, B. Am. Meteorol. Soc., 71, 1410-1428, 1990.

Kerkweg, A., Sander, R., Tost, H., and Jöckel, P.: Technical note: Implementation of prescribed (OFFLEM), calculated (ONLEM), and pseudo-emissions (TNUDGE) of chemical species in the Modular Earth Submodel System (MESSy), Atmos. Chem. Phys., 6, 3603-3609, doi:10.5194/acp-6-3603-2006, 2006a.

Kerkweg, A., Buchholz, J., Ganzeveld, L., Pozzer, A., Tost, H., and Jöckel, P.: Technical Note: An implementation of the dry removal processes DRY DEPosition and SEDImentation in the Modular Earth Submodel System (MESSy), Atmos. Chem. Phys., 6, 4617-4632, doi:10.5194/acp-6-4617-2006, 2006b.

Klonecki, A., Pommier, M., Clerbaux, C., Ancellet, G., Cammas, J.P., Coheur, P.-F., Cozic, A., Diskin, G. S., Hadji-Lazaro, J., Hauglustaine, D. A., Hurtmans, D., Khattatov, B., Lamarque, J.F., Law, K. S., Nedelec, P., Paris, J.-D., Podolske, J. R., Prunet, P., Schlager, H., Szopa, S., and Turquety, S.: Assimilation of IASI satellite $\mathrm{CO}$ fields into a global chemistry transport model for validation against aircraft measurements, Atmos. Chem. Phys., 12, 4493-4512, doi:10.5194/acp-12-4493-2012, 2012.

Koelemeijer, R. B. A., Stammes, P., Hovenier, J. W., and de Haan, J. F.: A fast method for retrieval of cloud parameters using oxygen A band measurements from the Global Ozone Monitoring Experiment, J. Geophys. Res., 106, 3475-3490, 2001.

Kopacz, M., Jacob, D. J., Fisher, J. A., Logan, J. A., Zhang, L., Megretskaia, I. A., Yantosca, R. M., Singh, K., Henze, D. K., Burrows, J. P., Buchwitz, M., Khlystova, I., McMillan, W. W., Gille, J. C., Edwards, D. P., Eldering, A., Thouret, V., and Nedelec, P.: Global estimates of CO sources with high resolution by adjoint inversion of multiple satellite datasets (MOPITT, AIRS, SCIAMACHY, TES), Atmos. Chem. Phys., 10, 855-876, doi:10.5194/acp-10-855-2010, 2010.

Lawrence, M. G., Crutzen, P. J., Rasch, P. J., Eaton, B. E., and Mahowald, N. M.: A model for studies of tropospheric photochemistry: Description, global distributions, and evaluation, J. Geophys. Res.-Atmos., 104, 26245-26277, 1999. 
Lawrence, M. G., Rasch, P. J., von Kuhlmann, R., Williams, J., Fischer, H., de Reus, M., Lelieveld, J., Crutzen, P. J., Schultz, M., Stier, P., Huntrieser, H., Heland, J., Stohl, A., Forster, C., Elbern, H., Jakobs, H., and Dickerson, R. R.: Global chemical weather forecasts for field campaign planning: predictions and observations of large-scale features during MINOS, CONTRACE, and INDOEX, Atmos. Chem. Phys., 3, 267-289, doi:10.5194/acp-3267-2003, 2003.

Lelieveld, J., Crutzen, P. J., Andreae, M. O., Brenninkmeijer, C. A. M., Campos, T., Cass, G. R., Dickerson, R. R., Fischer, H., de Gouw, J. A., Hansel, A., Jefferson, A., Kley, D., de Laat, A. T. J., Lal, S., Lawrence, M. G., Lobert, J. M., Mayol-Bracero, O., Mitra, A. P., Novakov, T., Oltmans, S. J., Prather, K. A., Ramanathan, V., Reiner, T., Rodhe, H., Scheeren, H. A., Sikka, D., and Williams, J.: The Indian Ocean Experiment: Widespread air pollution from South and South-East Asia, Science, 291, 10311036, 2001

Liu, C., Beirle, S., Butler, T., Liu, J., Hoor, P., Jöckel, P., Penning de Vries, M., Pozzer, A., Frankenberg, C., Lawrence, M. G., Lelieveld, J., Platt, U., and Wagner, T.: Application of SCIAMACHY and MOPITT CO total column measurements to evaluate model results over biomass burning regions and Eastern China, Atmos. Chem. Phys., 11, 6083-6114, doi:10.5194/acp11-6083-2011, 2011.

Liu, C., Beirle, S., Butler, T., Hoor, P., Frankenberg, C., Jöckel, P., Penning de Vries, M., Platt, U., Pozzer, A., Lawrence, M. G., Lelieveld, J., Tost, H., and Wagner, T.: CO profiles from SCIAMACHY observations using cloud slicing and comparison with model simulations, Atmos. Chem. Phys. Discuss., 13, 1165911688, doi:10.5194/acpd-13-11659-2013, 2013.

Liu, Junhua, Logan, J. A., Jones, D. B. A., Livesey, N. J., Megretskaia, I., Carouge, C., and Nedelec, P.: Analysis of CO in the tropical troposphere using Aura satellite data and the GEOS-Chem model: insights into transport characteristics of the GEOS meteorological products, Atmos. Chem. Phys., 10, 12207-12232, doi:10.5194/acp-10-12207-2010, 2010.

Logan, J. A., Prather, M. J., Wofsy, S. C., and Mcelroy, M. B.: Tropospheric Chemistry - a Global Perspective, J. Geophys. Res.Oc. Atm., 86, 7210-7254, 1981.

McMillan, W. W., Evans, K. D., Barnet, C. D., Maddy, E. S., Sachse, G. W., and Diskin, G. S.: Validating the AIRS Version 5 CO Retrieval With DACOM In Situ Measurements During INTEX-A and -B, IEEE T. Geosci. Remote, 49, 2802-2813, doi:10.1109/TGRS.2011.2106505, 2011.

Nakajima, T., and King, M. D.: Determination of the OpticalThickness and Effective Particle Radius of Clouds from Reflected Solar-Radiation Measurements .1. Theory, J. Atmos. Sci., 47, 1878-1893, 1990.

Nordeng, T. E.: Extended versions of the convective parametrization scheme at ECMWF and their impact on the mean and transient activity of the model in the Tropics, Tech. Rep., 2006, ECWMF, 1994.

Olivier, J. G. J. and Berdowski, J. J. M.: Global emissions sources and sinks, in: The Climate System, edited by: Berdowski, J., Guicherit, R., and Heij, B. J., A. A. Balkema Publishers/Swets and Zeitlinger Publishers, Lisse, the Netherlands, 33-78, 2001.

Pechony, O., Shindell, D. T., and Faluvegi, G.: Direct top-down estimates of biomass burning $\mathrm{CO}$ emissions using TES and MOPITT versus bottom-up GFED inventory, J. Geophys. Res., 118, 1-13, doi:10.1002/jgrd.50624, 2013.

Platnick, S.: A superposition technique for deriving mean photon scattering statistics in plane-parallel cloudy atmospheres, J. Quant. Spectrosc. Ra., 68, 57-73, 2001.

Pozzer, A., Jöckel, P., Tost, H., Sander, R., Ganzeveld, L., Kerkweg, A., and Lelieveld, J.: Simulating organic species with the global atmospheric chemistry general circulation model ECHAM5/MESSy1: a comparison of model results with observations, Atmos. Chem. Phys., 7, 2527-2550, doi:10.5194/acp-72527-2007, 2007.

Pozzer, A., Jöckel, P., and Van Aardenne, J.: The influence of the vertical distribution of emissions on tropospheric chemistry, Atmos. Chem. Phys., 9, 9417-9432, doi:10.5194/acp-9-9417-2009, 2009.

Rasch, P. J., Mahowald, N. M., and Eaton, B. E.: Representations of transport, convection, and the hydrologic cycle in chemical transport models: Implications for the modeling of short-lived and soluble species, J. Geophys. Res.-Atmos., 102, 28127-28138, 1997.

Rinsland, C. P., Luo, M., Logan, J. A., Beer, R., Worden, H. M., Kulawik, S. S., Rider, D., Osterman, G., Gunson, M., Eldering, A., Goldman, A., Shephard, M. W., Clough, S. A., Rodgers, C., Lampel, M. C., and Chiou, L.: Nadir measurements of carbon monoxide distributions by the Tropospheric Emission Spectrometer instrument onboard the Aura Spacecraft: Overview of analysis approach and examples of initial results, Geophys. Res. Lett., 33, L22806, doi:10.1029/2006GL027000, 2006.

Roeckner, E., Brokopf, R., Esch, M., Giorgetta, M., Hagemann, S., Kornblueh, L., Manzini, E., Schlese, R., and Schulzweida, U.: Sensitivity of simulated climate to horizontal and vertical resolution in the ECHAM5 atmosphere model, J. Climate, 19, 37713791, 2006.

Shindell, D. T., Faluvegi, G., Stevenson, D. S., Krol, M. C., Emmons, L. K., Lamarque, J. F., Petron, G., Dentener, F. J., Ellingsen, K., Schultz, M. G., Wild, O., Amann, M., Atherton, C. S., Bergmann, D. J., Bey, I., Butler, T., Cofala, J., Collins, W. J., Derwent, R. G., Doherty, R. M., Drevet, J., Eskes, H. J., Fiore, A. M., Gauss, M., Hauglustaine, D. A., Horowitz, L. W., Isaksen, I. S. A., Lawrence, M. G., Montanaro, V., Muller, J. F., Pitari, G., Prather, M. J., Pyle, J. A., Rast, S., Rodriguez, J. M., Sanderson, M. G., Savage, N. H., Strahan, S. E., Sudo, K., Szopa, S., Unger, N., van Noije, T. P. C., and Zeng, G.: Multimodel simulations of carbon monoxide: Comparison with observations and projected near-future changes, J. Geophys. Res.Atmos., 111, D19306, doi:10.1029/2006jd007100, 2006.

Sneep, M., de Haan, J. F., Stammes, P., Wang, P., Vanbauce, C., Joiner, J., Vasilkov, A. P., and Levelt, P. F.: Three-way comparison between OMI and PARASOL cloud pressure products, J. Geophys. Res., 113, D15S23, doi:10.1029/2007JD008694, 2008.

Tiedtke, M.: A comprehensive mass flux scheme for cumulus parameterization in large-scale models, Mon. Weather Rev., 117, 1779-1800, 1989.

Tost, H., Jöckel, P., and Lelieveld, J.: Influence of different convection parameterisations in a GCM, Atmos. Chem. Phys., 6, 54755493, doi:10.5194/acp-6-5475-2006, 2006.

Tost, H., Lawrence, M. G., Brühl, C., Jöckel, P., The GABRIEL Team, and The SCOUT-O3DARWIN/ACTIVE Team: Uncertainties in atmospheric chemistry modelling due to convection parameterisations and 
subsequent scavenging, Atmos. Chem. Phys., 10, 1931-1951, doi:10.5194/acp-10-1931-2010, 2010.

van der Werf, G. R., Randerson, J. T., Giglio, L., Collatz, G. J., Kasibhatla, P. S., and Arellano Jr., A. F.: Interannual variability in global biomass burning emissions from 1997 to 2004, Atmos. Chem. Phys., 6, 3423-3441, doi:10.5194/acp-6-3423-2006, 2006.

Veefkind, J. P., de Haan, J. F., Brinksma, E. J., Kroon, M., and Levelt, P. F.: Total ozone from the Ozone Monitoring Instrument (OMI) using the OMI-DOAS technique, IEEE T. Geosci. Remote, 44, 1239-1244, 2006.

von Kuhlmann, R., Lawrence, M. G., Crutzen, P. J., and Rasch, P. J.: A model for studies of tropospheric ozone and nonmethane hydrocarbons: Model description and ozone results, J. Geophys. Res.-Atmos., 108, 4294, doi:10.1029/2002jd002893, 2003.

Wang, P., Stammes, P., van der A, R., Pinardi, G., and van Roozendael, M.: FRESCO+: an improved $\mathrm{O}_{2}$ A-band cloud retrieval algorithm for tropospheric trace gas retrievals, Atmos. Chem. Phys., 8, 6565-6576, doi:10.5194/acp-8-6565-2008, 2008.

Worden, H. M., Deeter, M. N., Edwards, D. P., Gille, J. C., Drummond, J. R., and Nédélec, P.: Observations of near-surface carbon monoxide from space using MOPITT multispectral retrievals, J. Geophys. Res., 115, D18314, doi:10.1029/2010JD014242, 2010.

Worden, H. M., Deeter, M. N., Frankenberg, C., George, M., Nichitiu, F., Worden, J., Aben, I., Bowman, K. W., Clerbaux, C., Coheur, P. F., de Laat, A. T. J., Detweiler, R., Drummond, J. R., Edwards, D. P., Gille, J. C., Hurtmans, D., Luo, M., MartínezAlonso, S., Massie, S., Pfister, G., and Warner, J. X.: Decadal record of satellite carbon monoxide observations, Atmos. Chem. Phys., 13, 837-850, doi:10.5194/acp-13-837-2013, 2013a.

Worden, J., Wecht, K., Frankenberg, C., Alvarado, M., Bowman, K., Kort, E., Kulawik, S., Lee, M., Payne, V., and Worden, H.: $\mathrm{CH}_{4}$ and $\mathrm{CO}$ distributions over tropical fires during October 2006 as observed by the Aura TES satellite instrument and modeled by GEOS-Chem, Atmos. Chem. Phys., 13, 3679-3692, doi:10.5194/acp-13-3679-2013, 2013 b.
Wunch, D., Toon, G. C., Blavier, J.-F. L., Washenfelder, R. A., Notholt, J., Connor, B. J., Griffith, D. W. T., Sherlock, V., and Wennberg, P. O.: The Total Carbon Column Observing Network, Philos. T. R. Soc. A, 369, 2087-2112, doi:10.1098/rsta.2010.0240, 2011

Zhang, G. J. and McFarlane, N. A.: Sensitivity of climate simulations to the parameterization of cumulus convection in the Canadian climate centre general circulation model, Atmos.-Ocean, 33, 407-446, 1995.

Ziemke, J. R. and Chandra, S.: Seasonal and interannual variabilities in tropical tropospheric ozone, J. Geophys. Res., 104, 2142521442, doi:10.1029/1999JD900277, 1999.

Ziemke, J. R., Chandra, S., and Bhartia, P. K.: Two new methods for deriving tropospheric column ozone from TOMS measurements: The assimilate UARS MLS/HALOE and convective-cloud differential techniques, J. Geophys. Res., 103, 22115-22127, 1998.

Ziemke, J. R., Chandra, S., and Bhartia, P. K.: "Cloud slicing": A new technique to derive upper tropospheric ozone from satellite measurements, J. Geophys. Res., 106, 9853-9867, doi:10.1029/2000JD900768, 2001.

Ziemke, J. R., Joiner, J., Chandra, S., Bhartia, P. K., Vasilkov, A., Haffner, D. P., Yang, K., Schoeberl, M. R., Froidevaux, L., and Levelt, P. F.: Ozone mixing ratios inside tropical deep convective clouds from OMI satellite measurements, Atmos. Chem. Phys., 9, 573-583, doi:10.5194/acp-9-573-2009, 2009. 